\title{
Factors Associated with Long-Term Retention in Buprenorphine-Based Addiction Treatment Programs: a Systematic Review
}

\author{
Amy J. Kennedy, MD, MS ${ }^{\top} \odot$, Charles B. Wessel, MLS², Rebecca Levine, MD ${ }^{3}$, \\ Kendall Downer, $M D^{3}$, Megan Raymond, $B S^{4}$, Deborah Osakue, $M S^{3}$, \\ Iman Hassan, MD, MS ${ }^{5}$, Jessica S. Merlin, MD, MBA, PhD ${ }^{3,6}$, and Jane M. Liebschutz, \\ $\mathrm{MD}, \mathrm{MPH}^{3,6}$
}

\begin{abstract}
'Ambulatory Care Network, Department of Health Services, Los Angeles County, Los Angeles, CA, USA; ${ }^{2}$ Health Sciences Library Systems, University of Pittsburgh, Pittsburgh, PA, USA; ${ }^{3}$ Division of General Internal Medicine, University of Pittsburgh, Pittsburgh, PA, USA; ${ }^{4}$ University of Pittsburgh School of Medicine, Pittsburgh, PA, USA; ${ }^{5}$ Division of General Internal Medicine, Albert Einstein College of Medicine, Bronx, NY, USA; ${ }^{6}$ Center for Research on Health Care, Pittsburgh, PA, USA.
\end{abstract}

BACKGROUND: The average length of buprenorphine treatment for opioid use disorder is less than 6 months.

OBJECTIVE: We conducted a systematic review to determine what factors were associated with longer retention in buprenorphine treatment.

DESIGN: We searched Medline, Embase, and Cochrane Database of Systematic Reviews in February 2018. Articles were restricted to randomized controlled trials on human subjects, written in English, which contained $\geq$ 24 weeks of objective data on retention in buprenorphine treatment.

MAIN MEASURES: We assessed whether dose of buprenorphine, treatment setting, or co-administration of behavioral therapy was associated with retention rates.

KEY RESULTS: Over 14,000 articles were identified. Thirteen articles (describing 9 studies) met inclusion criteria. Measures of retention varied widely. Three studies compared doses of buprenorphine between 1 and $8 \mathrm{mg}$ and showed significantly higher rates of retention with higher doses ( $p$ values $<0.01$ ). All other studies utilized buprenorphine doses between 8 and $24 \mathrm{mg}$ daily, without comparison. No study found a significant difference in retention between buprenorphine alone and buprenorphine plus behavioral therapy ( $p$ values $>$ 0.05). Initiating buprenorphine while hospitalized or within criminal justice settings prior to outpatient treatment programs was significantly associated with retention in buprenorphine treatment ( $p$ values $<0.01$ respectively).

CONCLUSIONS: Setting of treatment initiation and a higher buprenorphine dose are associated with improved

Prior Presentations Preliminary results from this study were presented in abstract form at the Society of General Internal Medicine Annual Meeting in Washington D.C. in May 2019 and as an oral abstract at the Association for Multidisciplinary Education and Research in Substance Use and Addiction National Meeting in November 2019.

Received October 29, 2020

Accepted December 13, 2020

Published online January 19, 2021 long-term treatment retention. More objective data on buprenorphine treatment programs are needed, including a standardized approach to defining retention in buprenorphine treatment programs.

REGISTRATION: This review was registered with PROSPERO (\#CRD42019120336) in March 2019.

KEY WORDS: systematic review; buprenorphine; opioid use disorder; retention; long-term.

$\mathrm{J}$ Gen Intern Med 37(2):332-40

DOI: $10.1007 / \mathrm{s} 11606-020-06448-\mathrm{Z}$

(C) Society of General Internal Medicine 2021

\section{INTRODUCTION}

Millions of Americans live with opioid use disorder (OUD) ${ }^{1}$. When untreated, OUD leads to significant health consequences $^{2-4}$ and higher mortality than that observed in the general population ${ }^{5}, 6$. Buprenorphine is an evidence-based, first-line medication to treat $\mathrm{OUD}^{7}$. Not only does buprenorphine improve abstinence rates among individuals with $\mathrm{OUD}^{8,9}$, but it is also associated with improved morbidity and mortality for individuals on active treatment ${ }^{10}$. Buprenorphine is a medication used to treat OUD in the outpatient setting, as it can be prescribed by physicians, nurse practitioners, and physician assistants who have received a special waiver from the Drug Enforcement Agency.

Despite the benefits of buprenorphine in the treatment for OUD, the average length of treatment is less than 6 months, with only a minority of individuals remaining on the medication at 1 year ${ }^{1-13}$. Return to drug use is common after buprenorphine discontinuation ${ }^{14}$, with high rates of overdose among those lost to follow-up ${ }^{15}$. Retaining individuals in buprenorphine treatment (e.g., regular follow-up visits, longterm continuation of therapy) is critical to improve health outcomes for individuals with OUD.

Prior research has demonstrated highly variable retention rates of medication treatment for OUD ranging from 19 to 
$94 \%, 3$ to $88 \%$, and 37 to $91 \%$ at 3, 6, and 12 months, respectively ${ }^{16}$. Low retention may reflect the variability in treatment programs or types of medication therapy for OUD, and could also reflect the lack of consistency in measurement of retention. Prior systematic reviews on this topic have focused on assessing quality metrics ${ }^{17}$ and retention in all types of medication treatment programs ${ }^{16}$. Though buprenorphine is rapidly becoming a common medication for office-based treatment of OUD, less is known regarding what specific factors are associated with long-term buprenorphine retention. This is especially true regarding studies in which retention is measured objectively. In this systematic review, we analyzed factors associated with long-term retention in office-based buprenorphine treatment for OUD.

\section{METHODS}

This review was registered with PROSPERO (\#CRD42019120336) in March 2019.

\section{Data Sources and Searches}

We searched Medline, Embase, and the Cochrane Database of Systematic Reviews in February 2018 using the terms "buprenorphine agonists," "addiction/substance abuse/opiateopioid use," and "opiate substitution treatment." Our search string was developed and executed using the input of four coauthors (J.M.L., J.S.M., C.B.W., and A.J.K.), one of whom (C.B.W.) is a librarian with expertise in systematic reviews (see Appendix 1 for full search string). Search results were downloaded into an Endnote library, where duplicates were removed. Results were then uploaded to the DistillerSR (Evidence Partners) software program for review and screening.

\section{Study Selection}

Inclusion Criteria. Participants were limited to adolescents and adults (aged $>12$ years old) with diagnosed OUD who sought buprenorphine treatment at an outpatient treatment program. Studies from all settings where buprenorphine initiation occurred, including both inpatient and outpatient settings, were included in our analysis. There were no restrictions regarding date of publication. Articles were restricted to peer-reviewed, randomized controlled trials (RCTs) on human subjects, written in English that contained at least 24 weeks of objective data on retention in buprenorphine treatment. A minimum of 24 weeks was chosen for retention as we were most interested in long-term retention (i.e., 6 months to 1 year or longer). We defined an objective measure for retention in treatment as any outcome that listed data such as days retained in care, treatment days, study days, documented buprenorphine via blood or urine testing, or buprenorphine prescription fills.

Exclusion Criteria. We excluded articles if they comprised primarily minors (aged $<13$ years old), if they had no objective data on treatment retention, or if the study outcome was unrelated to treatment of OUD (e.g., neonatal abstinence syndrome, hepatitis C, HIV, tobacco use). We also excluded articles that did not describe buprenorphine as a treatment for OUD (i.e., if buprenorphine was administered only for pharmacokinetics, withdrawal, or detoxification) and those that contained no patient-level data (i.e., contained provideronly data, or were cost-effectiveness analysis or program evaluations). Though the majority of articles included buprenorphine co-formulated with naloxone, we did not exclude studies that assessed buprenorphine alone as treatment for OUD.

Data Collection. One author (A.J.K.) conducted an initial title screen on all articles. Four authors (A.J.K., R.L., M.R., and D.O.) performed an abstract and a full-text screen on the remaining articles (two authors per abstract). Any conflicts among authors in either the abstract or full-text review were resolved by the primary investigator (A.J.K.), along with the senior authors (J.S.M. and J.M.L.). A full description of screening questions by level is available in Appen$\operatorname{dix} 2$.

\section{Data Extraction and Strength of Evidence}

Data was extracted from each of the included studies using outcomes previously reported in the literature ${ }^{16,17}$, as well as a priori criteria iteratively determined by three of the authors (A.J.K., J.S.M., J.M.L.). Four authors (A.J.K., I.H., K.D., R.L.) independently performed data extraction (two authors per article) on all the included studies. Study authors were contacted for additional information or clarification if needed. All manuscripts describing data from the same study were utilized during this extraction (e.g., protocol and results papers).

Variables. Data items included sample description, study design, study duration, retention in OUD treatment, method of statistical analysis, and outcomes. Sample description included location of study, number of participants, and participant inclusion and exclusion criteria. Study design included the primary outcome, co-interventions, presence of a prior protocol paper, and type and frequency of behavioral intervention, if behavioral intervention was included. Study duration included number of weeks of intervention and duration of data collection/follow-up. The results included primary outcomes of the study and retention results, including how retention was measured if retention was not the primary outcome of the study. Data was included on illicit opioid use and how it was measured.

Strength of Evidence. We assessed for selection, performance, detection, attrition, and reporting bias utilizing the Cochrane Risk of Bias Tool for randomized controlled trials $^{18}$. Four authors (I.H., K.D., R.L., D.O.) independently assessed the studies (two authors per article). The primary 
investigator (A.J.K.) compared the risk of bias ratings and data extraction results and resolved any discrepancies with consultation from senior authors (J.S.M. and J.M.L.) when needed.

Data Synthesis and Analysis. Data were evaluated descriptively as the heterogeneity of the studies did not allow for a formal meta-analysis to be performed.

Role of Funding Source. This study was not directly supported by funding.

\section{RESULTS}

\section{Study Selection}

We identified 14,096 unique publications through February 2018; 4199 articles were screened at the abstract level and 610 at the full-text level. A total of 13 articles met final inclusion criteria, describing a total of 9 unique randomized controlled trials (Fig. 1) (19-27). All ( $n=9,100 \%)$ studies had greater than 100 participants. A majority of trials were single center $(n=7,78 \%)$ and from the USA $(n=6,67 \%)$. Most trials $(n=7,78 \%)$ excluded patients with co-morbid severe psychiatric disorders, and $5(55 \%)$ trials excluded pregnant women or required reproductive aged women to be on contraception (Table 1). All but one study $(n=8,89 \%)$ included some form of behavioral therapy for OUD.

\section{Retention in Buprenorphine Treatment}

All 9 RCTs provided objective measures of retention. Retention results varied among our studies (6-month retention, 10 69\%; 1-year retention, 49-59\%) (Table 2). There was significant heterogeneity in measurement of retention (Table 2). Measures included days in treatment $(n=6)$, retention at end of study $(n=2)$, urine drug testing for buprenorphine $(n=1)$, and medication monitoring $(n=1)$ (some studies used multiple methods to define treatment retention).

\section{Types of Studies}

We were able to further characterize the 9 RCTs that met the inclusion criteria in our review. Three of the studies compared doses of buprenorphine, 3 compared adjunctive behavioral therapy, and 4 looked at setting of care/frequency of dosing of buprenorphine.

\section{Buprenorphine Dose Trials}

Three trials, all performed in Iran between 2002 and 2004, compared doses of buprenorphine between 1 and $8 \mathrm{mg}$ and showed significantly higher rates of retention with higher doses $(63-78 \%$ retained in care for $4-8 \mathrm{mg}$ doses vs. 17$46 \%$ for $1-3 \mathrm{mg}$ doses; $p$ values $<0.01$; see Table 2 retained in care $)^{19-21}$. When data from the three studies were combined, retention appeared to increase with buprenorphine dose (Digital Appendix 3). All other included trials utilized maintenance buprenorphine doses between 8 and $24 \mathrm{mg}$ daily; none was designed to assess buprenorphine dose as an outcome (Table 2).

\section{Adjunctive Behavioral Therapy Trials}

Of the included trials, three compared buprenorphine with standard counseling versus buprenorphine plus intensive behavioral therapy $\mathrm{z}^{22-24}$. One trial examined standard versus longer duration counseling sessions ${ }^{22}$, one examined standard counseling versus cognitive behavioral therapy $(\mathrm{CBT})^{24}$, and one trial assessed standard counseling versus intensive outpatient therapy $(\mathrm{IOP})^{23}$. No study found a significant difference in retention between buprenorphine with standard counseling (43-59\% retained in care) and buprenorphine plus intensive behavioral therapy (39-57\% retained in care) ( $p$ values $>0.05$ ) (Table 2).

\section{Setting of Care Trials}

There were 4 trials that compared location and/or frequency of buprenorphine administration $^{22,25-27}$. Two trials assessed frequency of dosing of buprenorphine (once-daily dosing up to once-weekly dosing) $)^{22,27}$, one trial compared starting buprenorphine in criminal justice settings versus outpatient settings ${ }^{25}$, and one trial compared inpatient induction of buprenorphine and linkage of care versus standard referral and outpatient initiation (Table 1) ${ }^{26}$. Frequency of dosing of buprenorphine was not associated with retention in buprenorphine treatment (43-73\% retention at 24 weeks for less frequent dosing compared to 39-69\% for more frequent dosing), but starting buprenorphine prior to initiation in outpatient treatment programs (inpatient induction or within criminal justice settings) was significantly associated with retention in buprenorphine treatment ( $p$ values $<0.01)$ (Table 2).

\section{Cochrane Risk of Bias}

Overall, all trials had 1 or more domains that were at unclear to high risk of bias on the Cochrane Risk of Bias Score (Table 3). Four trials $(44 \%)$ had at least one domain considered to be at high risk of bias, and 7 trials (78\%) had two or more domains with an unclear risk of bias. The most common domains to have unclear or high risk of bias were blinding participants and personnel $(n=7,78 \%)$ and incomplete outcome data $(n=8$, $89 \%)$.

\section{DISCUSSION}

In this systematic review of randomized controlled trials of buprenorphine treatment programs for OUD, we found limited clinical trial data on factors associated with long-term retention. Of over 14,000 articles identified, only 9 met our criteria, with the majority of articles excluded for lack of long-term 


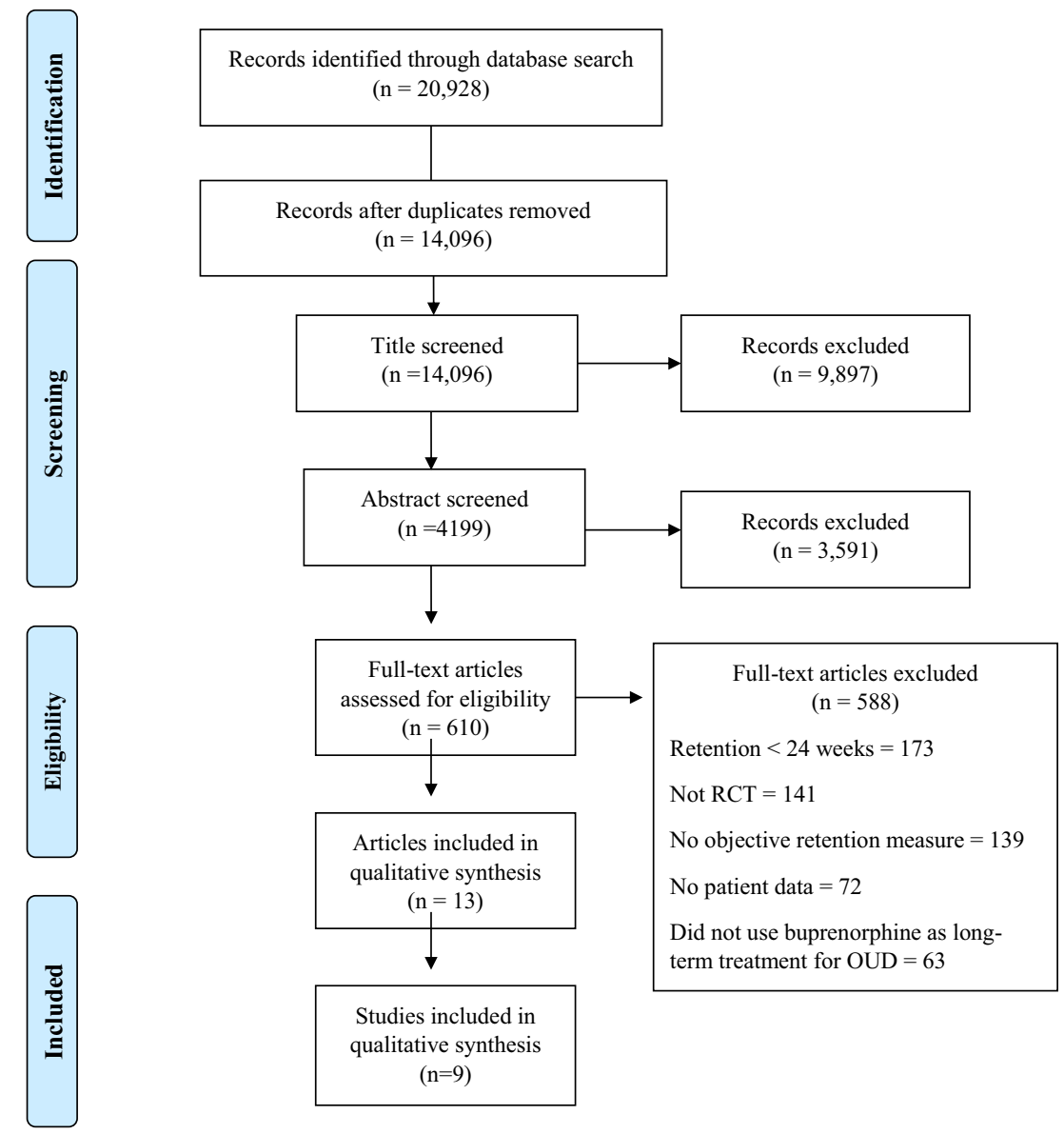

Figure 1 Flow diagram of selection process for randomized controlled studies assessing $\geq 2$-week retention in buprenorphine treatment programs.

follow-up and inconsistency in their measurement of retention results.

Retention in buprenorphine treatment was low for all RCTs included in our review. Almost half of all participants were no longer receiving treatment at 24 weeks. This is in line with prior studies on medication for OUD ${ }^{16}$. In Timko et al.'s (2016) review, RCTs evaluating retention in medication treatment programs for OUD (buprenorphine, naltrexone, and methadone) demonstrated extremely variable follow-up results: 19 to $94 \%$ at 3 months; 3 to $88 \%$ at 24 weeks; and 37 to $91 \%$ at 12 months $^{16}$. The patient populations and settings of care in our included studies were diverse, illustrating that retention in buprenorphine treatment is challenging across multiple settings. It is important to note that our systematic review focused on RCTs, which, given their rigorous recruitment and retention efforts, likely represent higher-thanaverage "real world" rates of retention. These data highlight the critical need to improve retention in buprenorphine treatment programs. More research is needed regarding what factors, both clinic level and patient level, are associated with retention in care.
Though limited by the rigor of the included studies, higher doses of buprenorphine did significantly increase retention in outpatient OUD programs. Though these trials were all completed in Iran in the early 2000s, with doses of buprenorphine between 1 and $8 \mathrm{mg}$ daily, their outcomes are in line with prior research, which has shown that higher doses of buprenorphine (up to $32 \mathrm{mg}$ daily), with flexibility in dosing, have better outcomes than strict adherence to lower doses ${ }^{13,28}$.

One notable finding of this review was that two RCTs found that initiating buprenorphine prior to establishment in an outpatient treatment program significantly increased retention in care ${ }^{25,26}$. In Liebschutz et al.'s (2014) trial, buprenorphine initiation in the hospital significantly improved retention, though the overall rates of retention in both arms of the trial were poor (total study 6-month retention was only $10-17 \%$ in the linkage group and $3 \%$ in nonlinkage group, respectfully) ${ }^{26}$. These low retention rates are considerably lower than those in the other studies in our review, which the authors suggest could reflect the complexities of hospitalized OUD patients, who often deal with 
Table 1 Study Type of Randomized Controlled Trials of Buprenorphine Retention

\begin{tabular}{|c|c|c|c|c|c|c|c|c|}
\hline $\begin{array}{l}\text { Author, } \\
\text { year }\end{array}$ & $N$ & Location & $\begin{array}{l}\text { Study } \\
\text { description }\end{array}$ & $\begin{array}{l}\text { Bup } \\
\text { dose }\end{array}$ & $\begin{array}{l}\text { Tnclusion and } \\
\text { exclusion criteria }\end{array}$ & $\begin{array}{l}\text { Study } \\
\text { retention* }\end{array}$ & $\begin{array}{l}\text { Behavioral } \\
\text { therapy }\end{array}$ & Comment \\
\hline \multicolumn{9}{|c|}{ Dosage of buprenorphine trials } \\
\hline $\begin{array}{l}\text { Ahmadi, } \\
2002\end{array}$ & 420 & $\begin{array}{l}\text { International, } \\
\text { urban, single site } \\
\text { Shiraz, Iran }\end{array}$ & $\begin{array}{l}1 \mathrm{mg} \text { vs. } 2 \mathrm{mg} \\
\text { vs. } 4 \mathrm{mg} \text { Bup } \\
\text { daily }\end{array}$ & $\begin{array}{l}1-4 \mathrm{mg} \\
\text { Bup }\end{array}$ & $\begin{array}{l}\text { Inclusion: DSM-IV for } \\
\text { OUD, daily opium use } \\
\text { for } 12 \text { months } \\
\text { Exclusion: serious } \\
\text { medical or psychiatric } \\
\text { condition, AUD, use } \\
\text { of methadone or } \\
\text { anticonvulsants }\end{array}$ & $24 \mathrm{~W}$ & $\begin{array}{l}\text { Offered weekly, } \\
1 \text {-h counseling } \\
\text { with addiction } \\
\text { psychiatrist }\end{array}$ & $\begin{array}{l}\text { Opium } \\
\text { dependent } \\
\text { only }\end{array}$ \\
\hline $\begin{array}{l}\text { Ahmadi, } \\
2003\end{array}$ & 123 & $\begin{array}{l}\text { International, } \\
\text { urban, single site } \\
\text { Shiraz, Iran }\end{array}$ & $\begin{array}{l}1 \mathrm{mg} \text { vs. } 3 \mathrm{mg} \\
\text { vs. } 8 \mathrm{mg} \text { Bup } \\
\text { daily }\end{array}$ & $\begin{array}{l}1-8 \mathrm{mg} \\
\text { Bup }\end{array}$ & $\begin{array}{l}\text { Inclusion: DSM-IV for } \\
\text { OUD, daily heroin use } \\
\text { for } 6 \text { months } \\
\text { Exclusions: serious } \\
\text { medical or psychiatric } \\
\text { condition, AUD, use } \\
\text { of methadone or } \\
\text { anticonvulsants }\end{array}$ & $12 \mathrm{M}$ & $\begin{array}{l}\text { Offered weekly, } \\
\text { 1-h counseling } \\
\text { with addiction } \\
\text { psychiatrist }\end{array}$ & $\begin{array}{l}\text { Heroin } \\
\text { dependent } \\
\text { only }\end{array}$ \\
\hline $\begin{array}{l}\text { Amadi, } \\
2004\end{array}$ & 513 & $\begin{array}{l}\text { International, } \\
\text { urban, single site } \\
\text { Shiraz, Iran }\end{array}$ & $\begin{array}{l}1 \mathrm{mg} \text { vs. } 3 \mathrm{mg} \\
\text { vs. } 8 \mathrm{mg} \text { Bup } \\
\text { daily }\end{array}$ & $\begin{array}{l}1-8 \mathrm{mg} \\
\text { Bup }\end{array}$ & $\begin{array}{l}\text { Inclusion: DSM-IV for } \\
\text { OUD, opium depen- } \\
\text { dence } \\
\text { Exclusions: age }<18 \\
\text { or }>85 \text { years, serious } \\
\text { medical or psychiatric } \\
\text { condition, AUD, use } \\
\text { of methadone or } \\
\text { anticonvulsants }\end{array}$ & $6 \mathrm{M}$ & $\begin{array}{l}\text { Offered weekly, } \\
\text { 1-h counseling } \\
\text { with addiction } \\
\text { psychiatrist }\end{array}$ & $\begin{array}{l}\text { Opium } \\
\text { dependent } \\
\text { only }\end{array}$ \\
\hline \multicolumn{9}{|c|}{ Adjunctive therapy trials } \\
\hline $\begin{array}{l}\text { Fiellin, } \\
2006^{\dagger}\end{array}$ & 166 & $\begin{array}{l}\text { USA, urban, } \\
\text { single site, } \\
\text { primary care } \\
\text { Yale, New } \\
\text { Haven, CT }\end{array}$ & $\begin{array}{l}\text { SM/1 weekly } \\
\text { vs. SM/3 } \\
\text { weekly vs. } \\
\text { EM/3 weekly }\end{array}$ & $\begin{array}{l}16-24 \\
\mathrm{mg} \\
\mathrm{Bup} / \mathrm{Na}\end{array}$ & $\begin{array}{l}\text { Inclusion: OUD on } \\
\text { OAT } \\
\text { Exclusion: AUD, } \\
\text { BUD, serious medical } \\
\text { or psychiatric } \\
\text { condition, women of } \\
\text { child-bearing age not } \\
\text { on contraception }\end{array}$ & $24 \mathrm{~W}$ & $\begin{array}{l}\text { SM: } 20 \text {-min } \\
\text { weekly sessions } \\
\text { EM: } 45 \text {-min } \\
\text { weekly session } \\
\text { All counseling } \\
\text { by primary care } \\
\text { nurses }\end{array}$ & $\begin{array}{l}\text { Could transfer } \\
\text { care if } \\
\text { unremitting } \\
\text { drug use }\end{array}$ \\
\hline $\begin{array}{l}\text { Mitchell, } \\
2013\end{array}$ & 300 & $\begin{array}{l}\text { USA, urban, } \\
\text { multi-site, CHC, } \\
\text { OTP }\end{array}$ & $\begin{array}{l}\text { Bup and OP } \\
\text { or Bup and } \\
\text { IOP }\end{array}$ & $\begin{array}{l}8-24 \\
\mathrm{mg} \\
\mathrm{Bup} / \mathrm{Na}\end{array}$ & $\begin{array}{l}\text { Inclusion: African } \\
\text { American, Bup } \\
\text { treatment for OUD } \\
\text { Exclusion: serious } \\
\text { medical or psychiatric } \\
\text { condition, pregnancy }\end{array}$ & $6 \mathrm{M}$ & $\begin{array}{l}\text { OP: } 2-8 \mathrm{~h} \\
\text { weekly counsel- } \\
\text { ing } \\
\text { IOP: } 9+\mathrm{h} \\
\text { weekly } \\
\text { counseling }\end{array}$ & $\begin{array}{l}\text { African- } \\
\text { American } \\
\text { only } \\
\text { IOP was } 5 \\
\text { h/week }\end{array}$ \\
\hline $\begin{array}{l}\text { Moore, } \\
2016\end{array}$ & 140 & $\begin{array}{l}\text { USA, urban, } \\
\text { single site, } \\
\text { primary care } \\
\text { Yale, New } \\
\text { Haven, CT }\end{array}$ & $\begin{array}{l}\text { Bup alone vs. } \\
\text { Bup plus CBT }\end{array}$ & $\begin{array}{l}16-24 \\
\mathrm{mg} \\
\mathrm{Bup} / \mathrm{Na}\end{array}$ & $\begin{array}{l}\text { Inclusion: DSM-IV for } \\
\text { OUD } \\
\text { Exclusion: AUD, } \\
\text { BUD, CUD, serious } \\
\text { medical or psychiatric } \\
\text { condition, women of } \\
\text { child-bearing age not } \\
\text { on contraception }\end{array}$ & $26 \mathrm{~W}$ & $\begin{array}{l}\text { Bup: } 20 \text {-min } \\
\text { counseling with } \\
\text { IM physicians } \\
\text { CBT: } 12 \text { weeks } \\
\text { of 50-min CBT } \\
\text { sessions with } \\
\text { master's or doc- } \\
\text { toral level clini- } \\
\text { cian }\end{array}$ & \\
\hline \multicolumn{9}{|c|}{ Setting of care trials } \\
\hline $\begin{array}{l}\text { Fiellin, } \\
2006^{\dagger}\end{array}$ & 166 & $\begin{array}{l}\text { USA, urban, } \\
\text { single site, } \\
\text { primary care } \\
\text { Yale, New } \\
\text { Haven, CT }\end{array}$ & $\begin{array}{l}\text { SM/1 weekly } \\
\text { vs. SM/3 } \\
\text { weekly vs. } \\
\text { EM/3 weekly }\end{array}$ & $\begin{array}{l}16-24 \\
\mathrm{mg} \\
\mathrm{Bup} / \mathrm{Na}\end{array}$ & $\begin{array}{l}\text { Inclusion: OUD on } \\
\text { OAT } \\
\text { Exclusion: AUD, } \\
\text { BUD, serious medical } \\
\text { or psychiatric } \\
\text { condition, women of } \\
\text { child-bearing age not } \\
\text { on contraception }\end{array}$ & $24 \mathrm{~W}$ & $\begin{array}{l}\text { SM: } 20 \text {-min } \\
\text { weekly sessions } \\
\text { EM: } 45-\text { min } \\
\text { weekly sessions } \\
\text { All by primary } \\
\text { care nurses. }\end{array}$ & $\begin{array}{l}\text { Could transfer } \\
\text { care if } \\
\text { unremitting } \\
\text { drug use }\end{array}$ \\
\hline $\begin{array}{l}\text { Gordon, } \\
2017\end{array}$ & 211 & $\begin{array}{l}\text { USA, urban, } \\
\text { multisite, } \\
\text { prisons, OTPs, } \\
\text { CHCs } \\
\text { Baltimore, MD }\end{array}$ & $\begin{array}{l}\text { Prison } \\
\text { Bup+OTP } \\
\text { referral } \\
\text { Prison } \\
\text { Bup+CHC } \\
\text { referral } \\
\text { Prison } \\
\text { counseling } \\
\text { +OTP referral } \\
\text { Prison } \\
\text { counseling } \\
\text { +CHC referral }\end{array}$ & $\begin{array}{l}8 \mathrm{mg} \\
\mathrm{Bup} / \mathrm{Na}\end{array}$ & $\begin{array}{l}\text { Inclusion: DSM-IV for } \\
\text { OUD, > } 18 \text { years, } \\
\text { within } 3-6 \text { months of } \\
\text { release, living in Bal- } \\
\text { timore post-release } \\
\text { Exclusion: liver or } \\
\text { kidney disease, } \\
\text { psychosis, pending } \\
\text { parole hearing, } \\
\text { un-adjudicated charges }\end{array}$ & $12 \mathrm{M}$ & $\begin{array}{l}\text { Initial } \\
\text { assessment and } \\
12 \text { weekly group } \\
\text { counseling } \\
\text { sessions }\end{array}$ & $\begin{array}{l}\text { Bup initiation } \\
\text { in criminal } \\
\text { justice setting }\end{array}$ \\
\hline & 139 & & & $16 \mathrm{mg}$ & & $6 \mathrm{M}$ & Does not specify & \\
\hline
\end{tabular}


Table 1. (continued)

\begin{tabular}{|c|c|c|c|c|c|c|c|c|}
\hline $\begin{array}{l}\text { Author, } \\
\text { year }\end{array}$ & $N$ & Location & $\begin{array}{l}\text { Study } \\
\text { description }\end{array}$ & $\begin{array}{l}\text { Bup } \\
\text { dose }\end{array}$ & $\begin{array}{l}\text { Inclusion and } \\
\text { exclusion criteria }\end{array}$ & $\begin{array}{l}\text { Study } \\
\text { retention* }\end{array}$ & $\begin{array}{l}\text { Behavioral } \\
\text { therapy }\end{array}$ & Comment \\
\hline $\begin{array}{l}\text { Liebschutz, } \\
2014\end{array}$ & & $\begin{array}{l}\text { USA, urban, } \\
\text { single-site, } \\
\text { hospital and } \\
\text { primary care, } \\
\text { Boston, MA }\end{array}$ & $\begin{array}{l}\text { Inpatient Bup } \\
+ \text { linkage vs. } \\
\text { Bup detox and } \\
\text { no linkage }\end{array}$ & $\mathrm{Bup} / \mathrm{Na}$ & $\begin{array}{l}\text { Inclusion: hospitalized, } \\
\text { opioid-dependent, age } \\
\text { > } 18 \text { years } \\
\text { Exclusion: prior Bup } \\
\text { or methadone, AUD, } \\
\text { BUD, self-harm, } \\
\text { surgery or jail time } \\
\text { pending, uncontrolled } \\
\text { pain, pregnancy }\end{array}$ & & & $\begin{array}{l}\text { Bup initiation } \\
\text { in hospital } \\
\text { patients }\end{array}$ \\
\hline $\begin{array}{l}\text { Marsch, } \\
2005\end{array}$ & 134 & $\begin{array}{l}\text { USA, single site, } \\
\text { OTP, VT }\end{array}$ & $\begin{array}{l}\text { Daily vs. } 2 \\
\text { weekly vs. } 3 \\
\text { weekly Bup } \\
\text { dosing }\end{array}$ & $\begin{array}{l}\text { 4-12 } \\
\text { mg } \\
\text { Bup }\end{array}$ & $\begin{array}{l}\text { Inclusion: DSM-IV for } \\
\text { OUD, age > } 18 \\
\text { Exclusion: serious } \\
\text { medical or psychiatric } \\
\text { condition, pregnancy }\end{array}$ & $24 \mathrm{~W}$ & $\begin{array}{l}\text { 1-h counseling/ } \\
\text { week with mas- } \\
\text { ter's level thera- } \\
\text { pist }\end{array}$ & \\
\hline
\end{tabular}

*Retention reported in weeks or months, depending on individual clinical trial

${ }^{\dagger}$ Fiellin study included both adjunctive therapy trial and setting of care trial

Abbreviations: N, number; AUD, alcohol use disorder; BUD, benzodiazepine or sedative use disorder; Bup, buprenorphine; Bup/Na, buprenorphinenaltrexone; CBT, cognitive behavioral therapy; CHC, community health center; CUD, cocaine use disorder; DSM-IV, Diagnostic and Statistical Manual of Mental Disorders, $4^{\text {th }}$ edition; EM, enhanced medical; IM, internal medicine; IOP, intensive outpatient therapy; min, minute; M, month; SM, standard medical; OAT, opioid agonist therapy; OTP, opioid treatment program; OP, standard outpatient therapy; OUD, opioid use disorder; W, week

more serious medical conditions than those traditionally starting in outpatient buprenorphine treatment. In a different venue, Gordon et al. (2017) found that persons who started buprenorphine within criminal justice settings had higher 1-year rates of retention in outpatient treatment than those who were referred after discharge ${ }^{25}$, which is consistent with prior research. Studies assessing short-term outcomes of starting buprenorphine in criminal justice settings have been similarly effective ${ }^{29-31}$. Though promising, more research is needed to determine if these results hold true in larger studies.

A subset of the RCTs in our review assessed buprenorphine treatment with and without adjunctive behavioral therapy. All three studies showed that the addition of behavioral therapy had no association with retention in care. Though these studies varied widely in the type of therapy offered (CBT vs. IOP vs. intensive counseling), they do add to other published works that suggest that behavioral therapy in conjunction with medication therapy may not significantly improve patient outcomes $^{32}$. Though behavioral therapy is important in many people's recovery process, our results suggest adding behavioral therapy to buprenorphine treatment may not impact retention rates.

Importantly, this review highlights the lack of objective data on long-term retention in buprenorphine treatment. Retention was measured in a variety of ways in our trials, and a large number of excluded studies either did not describe how they measured retention or used only self-reported data. Of those studies included, there was significant heterogeneity in how retention was measured (days in treatment, retention at end of study, medication monitoring). More objective measures of retention, such as urine screens for buprenorphine or documented prescription fills, are needed to better capture true retention in care. Now that prescription drug monitoring programs are in place throughout the majority of the country, documentation of prescription fills would be relatively straightforward and could be added to a clinical variable, such as days in treatment, to better capture true retention. As with other fields of research in which retention is an important outcome, such as $\mathrm{HIV}^{33}$, standardization in methodology is an important area for further development ${ }^{17,34}$.

Our review did have significant limitations. Given the heterogeneity of the trial outcomes, we were unable to perform a meta-analysis of all included studies. We chose to focus on the highest quality of evidence (RCTs), but this means we excluded observational data, which may have limited the data available to answer our question. We had only a small number of studies that met our inclusion criteria, many of which were performed over a decade ago, which made it difficult to apply their results within the current context of the opioid epidemic.

In future work, we plan to compare outcomes of long-term buprenorphine retention with that of methadone and naltrexone treatment programs. Novel programs, such as initiation of treatment outside of the clinic setting, need to be evaluated, as the current standard of care is not working. This review highlights the lack of high-quality studies on buprenorphine retention and the need for objective measures of retention to be standardized.

In conclusion, this systematic review found limited evidence on long-term retention in buprenorphine treatment programs. Of the 9 RCTs in our review, setting of treatment initiation and a higher buprenorphine dose were associated with improved long-term treatment retention, while adjunctive 
Table 2 Outcome Measures of Randomized Controlled Trials of Buprenorphine Retention

\begin{tabular}{|c|c|c|c|c|}
\hline Author, year & Retention measure & Retention results & Analysis comparison & Illicit opioid results \\
\hline \multicolumn{5}{|c|}{ Dosage of buprenorphine trials } \\
\hline $\begin{array}{l}\text { Ahmadi, } \\
2002\end{array}$ & Urine screen for Bup & $\begin{array}{l}24 \mathrm{~W} \text { retention } \\
\text { Total: } N=237 / 420(56 . \%) \\
1 \mathrm{mg}: 67 / 140(48 \%) \\
2 \mathrm{mg}: 78 / 140(56 \%) \\
4 \mathrm{mg}: 88 / 140(63 \%)\end{array}$ & $\begin{array}{l}4 \mathrm{mg} \text { Bup sig increased retention than } 2 \mathrm{mg} \\
(p<0.05) \text { and } 1 \mathrm{mg}(p<0.01) \text { groups. } \\
\text { No sex dif were observed }(p=0.84)\end{array}$ & N/A \\
\hline $\begin{array}{l}\text { Ahmadi, } \\
2003\end{array}$ & $\begin{array}{l}\text { Retention in study at } \\
12 \text { months }\end{array}$ & $\begin{array}{l}12 \mathrm{M} \text { retention } \\
\text { Total: } N=49 / 123(40 \%) \\
1 \mathrm{mg}: N=7 / 41(17 \%) \\
3 \mathrm{mg}: N=16 / 41(39 \%) \\
8 \mathrm{mg}: N=26 / 41(63 \%)\end{array}$ & $\begin{array}{l}8 \mathrm{mg} \text { Bup sig increased retention than } 3 \mathrm{mg} \\
(p=0.03) \text { and } 1 \mathrm{mg}(p<0.01) . \\
3 \mathrm{mg} \text { Bup sig increased retention than } 1 \mathrm{mg} \\
(p=0.03) .\end{array}$ & N/A \\
\hline Amadi, 2004 & $\begin{array}{l}\text { Retention in study at } \\
12 \text { months }\end{array}$ & $\begin{array}{l}12 \mathrm{M} \text { retention } \\
\text { Total: } N=282 / 513(55 \%) \\
1 \mathrm{mg}: N=46 / 171(27 \%) \\
3 \mathrm{mg}: N=102 / 171(60 \%) \\
8 \mathrm{mg}: N=134 / 171(78 \%)\end{array}$ & $\begin{array}{l}\text { All groups sig differed from each other at } p \\
<0.01 \text {. }\end{array}$ & $\mathrm{N} / \mathrm{A}$ \\
\hline \multicolumn{5}{|c|}{ Adjunctive therapy trials } \\
\hline Fiellin, $2006^{\dagger}$ & $\begin{array}{l}\text { Days in study, } \\
\text { medication bottle } \\
\text { monitoring }\end{array}$ & $\begin{array}{l}24 \mathrm{~W} \text { retention } \\
\text { Total: } N=72 / 166(43 \%) \\
\text { SM/1 weekly: } N=26 / 54 \\
(48 \%) \\
\text { SM/3 weekly: } N=24 / 56 \\
(43 \%) \\
\text { EM/3 weekly: } N=22 / 56 \\
(39 \%)\end{array}$ & $\begin{array}{l}\text { Mean number of patients who completed } \\
\text { study did not differ sig among the } 3 \text { groups } \\
(p=0.64) \text {. } \\
\text { Mean } \% \text { of days adherent to Bup was } \\
71+/-22 \% \text {, did not differ sig among groups } \\
(p=0.87) \text {. }\end{array}$ & $\begin{array}{l}\text { No sig dif between groups } \\
\text { in opioid use }(p=0.73) \\
\text { opioid-negative urine } \\
(p=0.82) \text {, nor weeks } \\
\text { abstinent }(p=0.54)\end{array}$ \\
\hline $\begin{array}{l}\text { Mitchell, } \\
2013\end{array}$ & Days in clinic & $\begin{array}{l}6 \mathrm{M} \text { retention } \\
\text { Total: } N=174 / 300(58 \%) \\
\text { Bup + OP: } N=91 / 155 \\
(59 \%) \\
\text { Bup + IOP: } N=83 / 145 \\
(57 \%)\end{array}$ & $\begin{array}{l}\text { No sig dif in retention in treatment }(\mathrm{Bup}+ \\
\mathrm{OP}=127.1 \text { days vs. Bup }+\mathrm{IOP}=126.9 \\
\text { days })(p=0.84)\end{array}$ & $\begin{array}{l}\text { No sig dif in OUD }(p= \\
0.67) \\
\text { or CUD }(p=0.63) \text { criteria }\end{array}$ \\
\hline Moore, 2016 & Days in study & $\begin{array}{l}26 \text { W retention } \\
\text { Total: } N=65 / 140(46 \%) \\
\text { Bup alone: } N=34 / 70(49 \%) \\
\text { Bup + CBT: } N=31 / 70 \\
(44 \%)\end{array}$ & $\begin{array}{l}\text { No sig dif in weeks completing treatment ( } p \\
=0.59) \text { or \# of weeks in treatment } \\
(p=0.67) \text { between groups. }\end{array}$ & $\begin{array}{l}\text { No sig dif in heroin use by } \\
\text { treatment }(p=0.33) \text {. } \\
\text { Sig dif in prescription } \\
\text { opioid use by treatment } \\
(p=0.04) \text {. }\end{array}$ \\
\hline \multicolumn{5}{|c|}{ Setting of care trials } \\
\hline Fiellin, $2006^{\dagger}$ & $\begin{array}{l}\text { Days in study, } \\
\text { medication bottle } \\
\text { monitoring }\end{array}$ & $\begin{array}{l}24 \mathrm{~W} \text { retention } \\
\text { Total: } N=72 / 166(43 \%) \\
\text { SM/1 weekly: } N=26 / 54 \\
(48 \%) \\
\text { SM/3 weekly: } N=24 / 56 \\
(43 \%) \\
\text { EM/3 weekly: } N=22 / 56 \\
(39 \%)\end{array}$ & $\begin{array}{l}\text { Mean number of patients who completed } \\
\text { study did not differ sig among the } 3 \text { groups } \\
(p=0.64) \text {. } \\
\text { Mean } \% \text { of days adherent to Bup was } \\
71+/-22 \% \text {, did not differ sig among groups } \\
(p=0.87) \text {. }\end{array}$ & $\begin{array}{l}\text { No sig dif between groups } \\
\text { in opioid use }(p=0.73) \\
\text { opioid-negative urine } \\
(p=0.82) \text {, nor weeks } \\
\text { abstinent }(p=0.54)\end{array}$ \\
\hline $\begin{array}{l}\text { Gordon, } \\
2017\end{array}$ & Days in clinic & $\begin{array}{l}6 \mathrm{M} \text { retention } \\
\text { Total: } N=140 / 211(66 \%) \\
12 \mathrm{M} \text { retention } \\
\text { Total: } N=124 / 211(59 \%)\end{array}$ & $\begin{array}{l}\text { Initiating Bup in prison had sig higher days } \\
\text { retained (mean 66) vs. initiating after } \\
\text { release (mean 22) }(p<0.01) \\
\text { Women were sig more likely to have } \\
\text { received Bup than men ( } 29 \% \text { vs. } 10 \% \\
p<0.05)\end{array}$ & $\begin{array}{l}\text { No sig dif in heroin } \\
\text { use between groups. }\end{array}$ \\
\hline $\begin{array}{l}\text { Liebschutz, } \\
2014\end{array}$ & Days in clinic & $\begin{array}{l}6 \mathrm{M} \text { retention } \\
\text { Total: } N=14 / 139(10 \%) \\
\text { Inpt Bup+link: } N=12 / 72 \\
(17 \%) \\
\text { Detox+no link: } N=2 / 67 \\
(3 \%)\end{array}$ & $\begin{array}{l}\text { Sig higher } 6 \text {-month retention in link than no } \\
\text { link }(p<0.01) \\
\text { Link group had Bup for mean } 65 \text { days vs. } 7 \\
\text { days for no link }(p<0.01)\end{array}$ & $\begin{array}{l}\text { Illicit opioid use was } \\
\text { sig lower in link than } \\
\text { no link }(p<0.01)\end{array}$ \\
\hline Marsch, 2005 & Days in clinic & $\begin{array}{l}24 \text { W retention } \\
\text { Total: } N=92 / 134(69 \%) \\
\text { Daily Bup: } N=31 / 45(69 \%) \\
2 \text { weekly Bup: } N=29 / 45 \\
(64 \%) \\
3 \text { weekly Bup: } N=32 / 44 \\
(73 \%)\end{array}$ & $\begin{array}{l}\text { No sig dif in retention at } 24 \text { weeks } \\
(p=0.74)\end{array}$ & $\begin{array}{l}\text { No sig dif in opioid } \\
(p=0.38) \text { or cocaine } \\
(p=0.46) \text { use }\end{array}$ \\
\hline
\end{tabular}

*Participant retention numbers not listed in paper, inferred based on percentages listed, subject to rounding error

${ }^{\dagger}$ Fiellin study included both adjunctive therapy trial and setting of care trial

${ }^{*}$ Study did not provide retention numbers for individual arms of study

Abbreviations: Bup, buprenorphine; CBT, cognitive behavioral therapy; $C H C$, community health center; CUD, cocaine use disorder; dif, difference; detox, buprenorphine detoxification; EM, enhanced medical; Inpt, inpatient; IOP, intensive outpatient therapy; link, linkage; M, month; Mod, moderate; $N$, number of participants; sig, significant; SM, standard medical; OTP, opioid treatment program; OP, standard outpatient therapy; OUD, opioid use disorder; $W$, week 
Table 3 Cochrane Risk of Bias Assessment for Buprenorphine Retention Trials

\begin{tabular}{|c|c|c|c|c|c|}
\hline Ahmadi 2002 & $?$ & $?$ & $?$ & ? & ? \\
\hline Ahmadi 2003 & $?$ & $?$ & + & ? & $?$ \\
\hline Ahmadi 2004 & $?$ & $?$ & 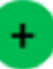 & $?$ & + \\
\hline Fiellin 2006 & + & + & $?$ & $?$ & + \\
\hline Gordon 2017 & + & + & ? & ? & + \\
\hline Liebschutz 2 & + & + & & & + \\
\hline Iarsch 2005 & $?$ & ? & & & + \\
\hline Litchell 2013 & $T$ & $T$ & & + & + \\
\hline Ioore 2016 & + & $?$ & $?$ & ? & $?$ \\
\hline
\end{tabular}

+ Low risk

? Unclear risk

High risk

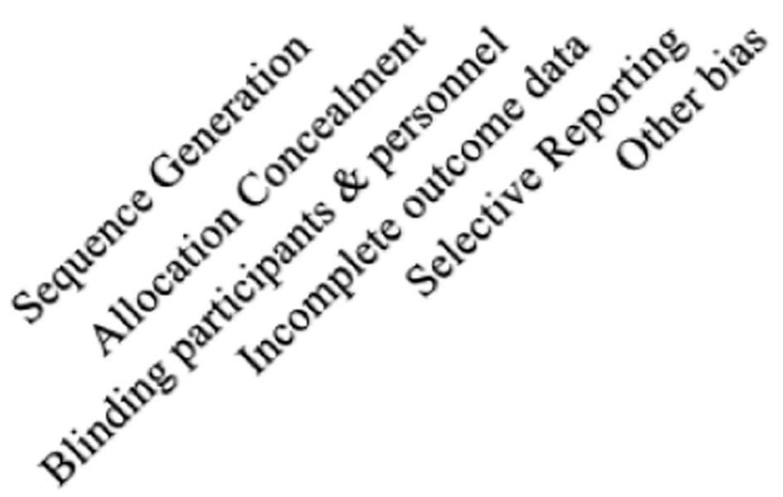

behavioral therapy or counseling in combination with buprenorphine did not lead to better retention in treatment compared to buprenorphine alone. More high-quality randomized controlled trials on buprenorphine treatment programs are needed to understand what factors impact retention in care. Future clinical trials on this subject should include a standardjzed approach to define retention in treatment.

Supplementary Information The online version contains supplementary material available at https://doi.org/10.1007/s11606-02006448-Z.

Acknowledgments: We wish to thank Ethan Lennox, MA, Division of General Internal Medicine, University of Pittsburgh School of Medicine, for his help with manuscript editing; Mary Lou Klem, PhD, MLIS, from the University of Pittsburgh Health Sciences Library for her assistance on data management; and Dr. Nader Shaikh, MD, and Dr. Kaleab Abebe, PhD, of the University of Pittsburgh School of Medicine, for their feedback on manuscript revisions.

Corresponding Author: Jane M. Liebschutz, MD, MPH; Division of General Internal Medicine, University of Pittsburgh, Pittsburgh, PA 15213, USA (e-mail: liebschutzjm@upmc.edu).
Funding The first author was supported by a HRSA T32 (T32HP22240) training grant for the duration of the data analysis and writing of the manuscript.

\section{Compliance with Ethical Standards:}

Conflict of Interest: The authors declare no conflict of interest.

\section{REFERENCES}

1. National Survey on Drug Use and Health. 2018 NSDUH Annual National Report | CBHSQ. Annual Report.

2. Ronan M V., Herzig SJ. Hospitalizations related to opioid abuse/ dependence and associated serious infections increased sharply, 200212. Health Aff. 2016;35(5):832-837. https://doi.org/10.1377/hlthaff. 2015. 1424

3. Zibbell JE, Asher AK, Patel RC, et al. Increases in Acute Hepatitis C Virus Infection Related to a Growing Opioid Epidemic and Associated Injection Drug Use, United States, 2004 to 2014. Am J Public Health. 2018;108(2):175-181. https://doi.org/10. 2105/AJPH.2017.304132

4. Peters PJ, Pontones P, Hoover KW, et al. HIV infection linked to injection use of oxymorphone in Indiana, 2014-2015. N Engl $\mathrm{J}$ Med. 2016;375(3):229-239. https://doi.org/10.1056/NEJMoa1515195 
5. Degenhardt L, Randall D, Hall W, Law M, Butler T, Burns L. Mortality among clients of a state-wide opioid pharmacotherapy program over 20 years: Risk factors and lives saved. Drug Alcohol Depend. 2009;105(12):9-15. https://doi.org/10.1016/j.drugalcdep.2009.05.021

6. Grönbladh L, Öhlund LS, Gunne LM. Mortality in heroin addiction: impact of methadone treatment. Acta Psychiatr Scand. 1990;82(3):223227. https://doi.org/10.1111/j.1600-0447.1990.tb03057.x

7. Kampman K, Jarvis M. American Society of Addiction Medicine (ASAM) national practice guideline for the use of medications in the treatment of addiction involving opioid use. J Addict Med. 2015;9(5):358-367. https:// doi.org/10.1097/ADM.0000000000000166

8. Fudala PJ, Bridge TP, Herbert S, et al. Office-based treatment of opiate addiction with a sublingual-tablet formulation of buprenorphine and naloxone. $N$ Engl $J$ Med. 2003;349(10):949-958. https://doi.org/10. 1056/NEJMoa022164

9. Mattick RP, Breen C, Kimber J, Davoli M. Buprenorphine maintenance versus placebo or methadone maintenance for opioid dependence. Cochrane Database Syst Rev. 2014;2014(2). https://doi.org/10.1002/ 14651858.CD002207.pub4

10. Pearce LA, Min JE, Piske M, et al. Opioid agonist treatment and risk of mortality during opioid overdose public health emergency: Population based retrospective cohort study. BMJ. 2020;368. https://doi.org/10. 1136/bmj.m772

11. Larochelle MR, Bernson D, Land T, et al. Medication for opioid use disorder after nonfatal opioid overdose and association with mortality: A cohort study. Ann Intern Med. 2018;169(3):137-145. https://doi.org/10. 7326/M17-3107

12. Tkacz J, Severt J, Cacciola J, Ruetsch C. Compliance with buprenorphine medication-assisted treatment and relapse to opioid use. Am J Addict. 2012;21(1):55-62. https://doi.org/10.1111/j.1521-0391.2011.00186.x

13. Morgan JR, Schackman BR, Leff JA, Linas BP, Walley AY. Injectable naltrexone, oral naltrexone, and buprenorphine utilization and discontinuation among individuals treated for opioid use disorder in a United States commercially insured population. J Subst Abuse Treat. 2018;85:90-96. https://doi.org/10.1016/j.jsat.2017.07.001

14. Bentzley BS, Barth KS, Back SE, Book SW. Discontinuation of buprenorphine maintenance therapy: Perspectives and outcomes. $J$ Subst Abuse Treat. 2015;52:48-57. https://doi.org/10.1016/j.jsat. 2014.12.011

15. Cornish R, Macleod J, Strang J, Vickerman P, Hickman M. Risk of death during and after opiate substitution treatment in primary care: Prospective observational study in UK General Practice Research Database. BMJ. 2010;341(7779):928. https://doi.org/10.1136/bmj.c5475

16. Timko C, Schultz NR, Cucciare MA, Vittorio L, Garrison-Diehn C. Retention in medication-assisted treatment for opiate dependence: A systematic review. J Addict Dis. 2016;35(1):22-35. https://doi.org/10. 1080/10550887.2016.1100960

17. Williams AR, Nunes E V., Bisaga A, et al. Developing an opioid use disorder treatment cascade: A review of quality measures. J Subst Abuse Treat. 2018;91:57-68. https://doi.org/10.1016/j.jsat.2018.06.001

18. Higgins JPT, Altman DG, Gøtzsche PC, et al. The Cochrane Collaboration's tool for assessing risk of bias in randomised trials. BMJ. 2011;343(7829). https://doi.org/10.1136/bmj.d5928

19. Ahmadi J, Bahrami N. Buprenorphine treatment of opium-dependent outpatients seeking treatment in Iran. J Subst Abuse Treat. 2002;23(4):415-417. https://doi.org/10.1016/S0740-5472(02)00272-6

20. Ahmadi J, Ahmadi $\mathbf{M}$. Twelve-month maintenance treatment of heroindependent outpatients with buprenorphine. J Subst Use. 2003;8(1):3941. https://doi.org/10.1080/1465989031000067236

21. Ahmadi J, Babaee-Beigi M, Alishahi M, Maany I, Hidari T. Twelvemonth maintenance treatment of opium-dependent patients. $J$ Subst Abuse Treat. 2004;26(1):61-64. https://doi.org/10.1016/S07405472(03)00141-7
22. Fiellin DA, Pantalon M V., Chawarski MC, et al. Counseling plus buprenorphine-naloxone maintenance therapy for opioid dependence. $N$ Engl J Med. 2006;355(4):365-374. https://doi.org/10.1056/ NEJMoa055255

23. Mitchell SG, Gryczynski J, Schwartz RP, O'Grady KE, Olsen YK, Jaffe JH. A randomized trial of intensive outpatient (IOP) vs. standard outpatient (OP) buprenorphine treatment for African Americans. Drug Alcohol Depend. 2013;128(3):222-229. https://doi.org/10.1016/j. drugalcdep.2012.08.027

24. Moore BA, Fiellin DA, Cutter CJ, et al. Cognitive Behavioral Therapy Improves Treatment Outcomes for Prescription Opioid Users in Primary Care Buprenorphine Treatment. J Subst Abuse Treat. 2016;71:54-57. https://doi.org/10.1016/j.jsat.2016.08.016

25. Gordon MS, Kinlock TW, Schwartz RP, O'Grady KE, Fitzgerald TT, Vocci FJ. A randomized clinical trial of buprenorphine for prisoners: Findings at 12-months post-release. Drug Alcohol Depend. 2017;172:3442. https://doi.org/10.1016/j.drugalcdep.2016.11.037

26. Liebschutz JM, Crooks D, Herman D, et al. Buprenorphine treatment for hospitalized, opioid-dependent patients: A randomized clinical trial. JAMA Intern Med. 2014;174(8):1369-1376. https://doi.org/10.1001/ jamainternmed.2014.2556

27. Marsch LA, Bickel WK, Badger GJ, Jacobs EA. Buprenorphine treatment for opioid dependence: The relative efficacy of daily, twice and thrice weekly dosing. Drug Alcohol Depend. 2005;77(2):195-204. https:// doi.org/10.1016/j.drugalcdep.2004.08.011

28. Ling W, Wesson DR, Charuvastra C, Klett CJ. A controlled trial comparing buprenorphine and methadone maintenance in opioid dependence. Arch Gen Psychiatry. 1996;53(5):401-407. https://doi.org/10. 1001/archpsyc.1996.01830050035005

29. Garcia CA, Correa GC, Viver ADH, et al. Buprenorphine-naloxone treatment for pre-release opioid-dependent inmates in Puerto Rico. $J$ Addict Med. 2007;1(3):126-132. https://doi.org/10.1097/ADM. Ob013e31814b8880

30. Magura S, Lee JD, Hershberger J, et al. Buprenorphine and methadone maintenance in jail and post-release: A randomized clinical trial. Drug Alcohol Depend. 2009;99(1-3):222-230. https://doi.org/10.1016/j. drugalcdep.2008.08.006

31. Zaller N, McKenzie M, Friedmann PD, Green TC, McGowan S, Rich JD. Initiation of buprenorphine during incarceration and retention in treatment upon release. $J$ Subst Abuse Treat. 2013;45(2):222-226. https://doi.org/10.1016/j.jsat.2013.02.005

32. Dugosh K, Abraham A, Seymour B, McLoyd K, Chalk M, Festinger D. A Systematic Review on the Use of Psychosocial Interventions in Conjunction with Medications for the Treatment of Opioid Addiction. $J$ Addict Med. 2016;10(2):93-103. https://doi.org/10.1097/ADM. 0000000000000193

33. Gardner EM, McLees MP, Steiner JF, Del Rio C, Burman WJ. The spectrum of engagement in HIV care and its relevance to test-and-treat strategies for prevention of HIV infection. Clin Infect Dis. 2011;52(6):793800. https://doi.org/10.1093/cid/ciq243

34. Williams AR, Nunes E V., Bisaga A, Levin FR, Olfson M. Development of a Cascade of Care for responding to the opioid epidemic. Am $J$ Drug Alcohol Abuse. 2019;45(1):1-10. https://doi.org/10.1080/00952990. 2018.1546862

Publisher's Note: Springer Nature remains neutral with regard to jurisdictional claims in published maps and institutional affiliations. 